\title{
Over representation of the A allele in the IL23R rs1004819 polymorphism in M694V homozygote non-responsive FMF patients
}

\author{
E Pras ${ }^{1,2^{*}}$, S Dahan ${ }^{1,2}$, A Epstein ${ }^{1,2}$, I Ben Zvi ${ }^{1,2}$, D Marek-Yagel ${ }^{1}$, Y Shinar ${ }^{1}$, M Lidar ${ }^{1,2}$, A Livneh ${ }^{1,2}$
}

From 8th International Congress of Familial Mediterranean Fever and Systemic Autoinflammatory Diseases Dresden, Germany. 30 September - 3 October 2015

\section{Objectives}

Recent studies have shown that interleukin-23 receptor (IL23R) polymorphisms confer susceptibility to ankylosing spondylitis, psoriasis, psoriatic arthritis and Crohn's disease. The A allele of rs1004819 was found in a significantly higher frequency among patients suffering from these diseases compared to controls. We aimed to determine the affect of rs1004819 in M694V homozygote FMF patients.

\section{Methods}

We typed 59 M694V homozygote FMF patients for the rs1004819 polymorphism, 27 of whom were defined as non responders to colchicine treatment. In addition we typed 57 ethnically matched controls.

\section{Results}

We found an over representation of the A allele in the non responders (A-29, G-25) as compared to the controls $(\mathrm{A}-33, \mathrm{G}-77)(\mathrm{p}=0.01)$, while a similar frequency was found between the responders (A-24, G-40) and the controls $(\mathrm{p}=0.3)$.

\section{Conclusions}

These results suggest that IL23 and its pathways are involved in the FMF inflammatory response. This association may provide new insights and treatment possibilities for FMF patients who do not respond to colchicine.

\section{Authors' details}

${ }^{1}$ Sheba Medical Center, Ramat Gan, Israel. ${ }^{2}$ Tel Aviv University, Tel Aviv, Israel.

Published: 28 September 2015

${ }^{1}$ Sheba Medical Center, Ramat Gan, Israel

Full list of author information is available at the end of the article
doi:10.1186/1546-0096-13-S1-P87

Cite this article as: Pras et al: Over representation of the $A$ allele in the IL23R rs1004819 polymorphism in M694V homozygote non-responsive FMF patients. Pediatric Rheumatology 2015 13(Suppl 1):P87.
Submit your next manuscript to BioMed Central and take full advantage of:

- Convenient online submission

- Thorough peer review

- No space constraints or color figure charges

- Immediate publication on acceptance

- Inclusion in PubMed, CAS, Scopus and Google Scholar

- Research which is freely available for redistribution
C Biomed Central 